\title{
Gi-Wook Shin and Daniel Sneider (eds), History Textbooks and the Wars in Asia,
}

New York, Routledge, 2011, 312 pp.

\section{Yves Russell}

Translator. N. Jayaram

\section{(2) OpenEdition}

\section{Journals}

Electronic version

URL: http://journals.openedition.org/chinaperspectives/6494

DOI: 10.4000/chinaperspectives.6494

ISSN: 1996-4617

\section{Publisher}

Centre d'étude français sur la Chine contemporaine

\section{Printed version}

Date of publication: 1 June 2014

Number of pages: $79-81$

ISSN: 2070-3449

\section{Electronic reference}

Yves Russell, " Gi-Wook Shin and Daniel Sneider (eds), History Textbooks and the Wars in Asia, », China Perspectives [Online], 2014/2 | 2014, Online since 01 January 2017, connection on 23 September 2020 URL : http://journals.openedition.org/chinaperspectives/6494; DOI : https://doi.org/10.4000/ chinaperspectives.6494

This text was automatically generated on 23 September 2020.

(c) All rights reserved 


\section{Gi-Wook Shin and Daniel Sneider (eds), History Textbooks and the Wars}

\section{in Asia,}

New York, Routledge, 2011, 312 pp.

\section{Yves Russell}

Translation : N. Jayaram

\section{Since the publication of History Textbooks and} the Wars in Asia in 2011, territorial and historical disputes among China, Japan, and Korea have hardly subsided. On the contrary, current disputes (regarding sovereignty over the Diaoyu/Senkaku islands, visits to the Yasukuni shrine by members of the Abe government, disputes over history textbooks, etc.) are often rooted in the divided memory of a "past that does not go away," thus preventing firm and lasting reconciliation. Following on from the first part of a research project $^{1}$ entitled "Divided memories and Reconciliation" by the Walter H. Shorenstein Asia-Pacific Research Center (Shorenstein APARC) of Stanford University, this book edited by Daniel C. Sneider and Gi-Wook Shin examines historical reconciliation in the region by "understanding how historical

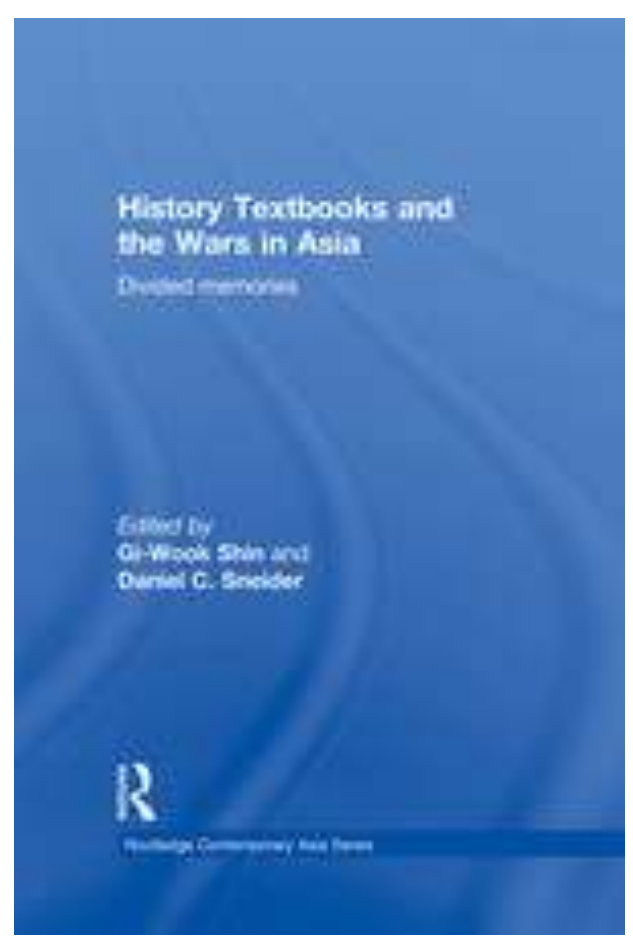
memory has evolved in each country and has been incorporated into respective master narratives" (p. 8). The Shorenstein APARC team translated and studied school history textbooks from Japan, South Korea, China, Taiwan, and the United States. 
2 This book makes two major contributions to existing literature on the problem of history textbooks in East Asia. The first is to present in parallel form 70 pages of excerpts from textbooks (in Part Two). The published extracts cover eight controversial themes from the 1931-1951 period: 1) the Nanjing Massacre; 2) the atomic bombing of Japanese cities; 3) origins of the Korean War; 4) Pearl Harbor; 5) forced labour and comfort women; 6) the Manchurian Incident; 7) economic development under Japanese rule; and 8) the Tokyo war crimes tribunal. This section is a rich source of first-hand information on the discourse and vocabulary used in national textbooks (three to five versions were used for each country) to describe the same events. It was decided to select textbooks widely circulated and used in each country and not the extremist ones (such as the Tsukuru-kai "New History Textbooks" in Japan, which are deemed revisionist), but regrettably there is little information on the chosen editions. The lay reader has to wait for the contribution by Alisa Jones (Chapter 7) to learn of the context and evolution of history textbook production, although no precise light is shed on the texts analysed. Similarly, it is only in Chapter 8 that the selection of themes is explained: they were identified as controversial by a Japan-China-Korea committee on common history teaching materials, which was charged with coming up with a common textbook published in 2005.

3 The second contribution of this study is the inclusion of American textbooks; Shin and Sneider believe that reconciliation in East Asia needs US participation: "The United States has been deeply involved in Northeast Asian affairs since 1941 and even before" (Shin, p. 10). A question arises as to the nature of such participation and whether it is not rather late already, and whether it might open up a new series of endless disputes, but the authors believe the Americans can be an example helping the Japanese to reconsider their history. They hold that "Japan's problem of history is an American problem as well," and quoting G. John Ikenberry, that "Washington should encourage Japan to pursue [a] German path, tying 'normalization' to redoubled commitments to regional security cooperation." (p. 12)

Meanwhile, conclusions arrived at in much of the book appear to partly discount the editors' hopes for an East Asian reconciliation. Part three contains five analyses comparing ways in which different textbooks narrate certain episodes from the 1931-1951 war era. The text extracts in Part Two and the subsequent analyses reveal that reconciliation perhaps depends on too many players with contradictory interests and that it is difficult to imagine it happening in the short or medium term without everyone's involvement. In fact, one of the main obstacles to overcome is the incompatibility of national histories taught in the various countries concerned. Parallel readings of Japan's and neighbouring countries' history clearly reveals - and this is one of the book's great strengths - that if they minimise or omit some of the most serious aspects of the war era (especially regarding Korea), Japanese textbooks do not highlight patriotism, revisionism, or nationalism or seek to justify the war - rather the contrary. Nor do they avoid the Nanjing Massacre and atrocities committed on civilians. According to Peter Duus (Chapter 1), whereas American textbooks narrate war history like a "nation-building story" (national Bildungsroman), and Chinese textbooks - both in the PRC and Taiwan - contain heroic stories of "resistance" and "liberation," those in Japan limit themselves to presenting events in a chronological style, the Imperial Army taking pride of place. It is "History without a story," and "compared to American and Chinese history textbooks, their tune is muted, neutral, and almost bland" (p. 110).

5 Hiroshi Mitani's excellent contribution throws candid and balanced light on the reasons for this "blandness" in Japanese textbooks. Regulations governing their publication "are the outcomes of many severe controversies in Japan from the 1960s to the 1990s," says Mitani, himself an historian and editor of textbooks engaged in the project for a common Japanese- 
Chinese-Korean textbook; which is why Japanese textbooks now need to be conceived and published keeping in view East Asian neighbours, "from the viewpoint of promoting international understanding and cooperation." Obliquely dealing with the dispute pitting Japan against its Asian neighbours on the issue of historical memory, Mitani relates also the dispute between inhabitants of Okinawa and the Education Ministry in 2007. ${ }^{2}$ This dispute shows the difficulty of compromising with victims' memory in the face of which the professional historian is bereft: the complex and nuanced academic history cannot satisfy the victims, who want to read history in line with their own memories.

This is also stated, albeit differently in the contributions of Haruo Tomatsu and Li Weike, who compare point by point the ways in which different countries' textbooks have dealt with the eight controversial themes (Chapters 2 and 3), ${ }^{3}$ by Chung Jaejung on the way Koreans were treated during Japan's occupation (Chapter 4), and finally by Hsin-Huang Michael Hsiao on the memories of Japanese colonialism in Korea and Taiwan. Textbooks in countries considering themselves "victims" of Japanese imperialism focus on traumatic episodes that concern their own nations the most, with little commiseration for neighbours. Korean textbooks, for instance, barely mention Manchuria, with little information on Pearl Harbor, and simply ignore the atomic bombs dropped on Hiroshima and Nagasaki. Textbooks published under the Chinese Communist Party's iron rule share with those on the peninsula a strong politicisation of texts, glorification of the nation and demonisation of enemies, as well as relative indifference towards neighbouring peoples' suffering (Haruo Tohmatsu, Chapter 2, p. 132). Li Weike, himself an editor of school textbooks at the People's Education Press in Beijing, inadvertently confirms Tohmatsu's conclusion by declaring, in the context of the Nanjing Massacre: "As the Chinese textbooks describe it, the Japanese invaders entered this civilized ancient capital like a pack of ferocious beasts and immediately proceeded to subject the peaceful Nanjing citizens to six long weeks of frenzied mass murder" (Chapter 3, p. 143).

7 The above passage reveals a second major obstacle to regional reconciliation. The texts are more "passionate" (and often below academic standards, some authors note) in Korea and China because nation-building is still a priority objective there. Peter Duus stresses that history textbooks' main function is to fashion national identities, and this aim guides the editing of historic texts. Duus, who writes on Japanese history, says the difficulty in writing a transnational history lies more in the difficulty of agreeing on the story than on "facts." Writing a common history by abandoning national narrative structures is thus "intellectually feasible" but "may not be politically feasible" (p. 103).

8 The book's fourth and last part highlight all the difficulties faced in the project for a transnational history. Soon-Won Park narrates the pitfall-filled process of writing common history textbooks for all three countries or bilaterally (Chapter 8). The fruit of this cooperation, A History that Opens to the Future - more a teaching guide than a textbook - failed to end the "war over words" described in the next chapter by Daniel Sneider, but helped a growing intellectual community to take into account the nature and reasons for neighbouring countries' historical perceptions. Sneider, director of the Divided Memories and Reconciliation project, traces in synthesis the different disputes in the region over history textbooks (Chapter 9). As Europe offers an oft-cited example of successful resolution of such disputes, Germany having been able to - obliged to - face its past with credit, Daniel Chirot shows how the geopolitical post-war situations of Japan and Germany were radically different (Chapter 10). While the United States played an ambiguous role in Japan in the context of the Cold War, it pressed West Germany to accept its culpability and educate future generations so as to avoid new bursts of bellicose nationalism. The power and capacity for pressure on the part of 
European neighbours such as Britain and France was also in a different class from that of Korea or China, caught up as they were in civil wars. Chirot nevertheless remains optimistic about Japan's ability to account for its aggressive past sometime in the near future, especially as the social context (disappearance of the generation that experienced war) as well as economic and geopolitical ones will facilitate it: "Particularly as American domination of the Pacific wanes, Japan, China, and Korea will see that it is to their advantage to take steps toward greater political accommodation to go along with their economic cooperation" (p. 282). This view is not shared by Alisa Jones (Chapter 7), who astutely traces the key elements in policies towards production of history textbooks in China, South Korea, and Taiwan: "Official historical narrative [...] is designed to promote national identification and to legitimize the current regime or political system" (p. 224). However, the national contexts distort understanding of other countries' realities. The dominant - and convenient - idea in China and Korea that Japanese textbooks stem from strict governmental control may be "attributable to the tight regulation and relative narrative homogeneity of the history textbooks to which Chinese, South Koreans, and Taiwanese are accustomed and lead them to project the notion of a uniform national story onto Japan's textbooks. Whatever the trigger, this assumption allows such misperceptions about the narrative content of Japanese history textbooks to persist and fan the flames of anti-Japanese sentiment. It is not hard to see the irony in Chinese and Korean attacks on far more plural Japanese textbooks for 'historical revisionism' when they are busy revising their own to legitimize their polities and drown out dissent. And if historical pluralism cannot be tolerated between parties at home, what hope can there be for historical reconciliation between countries?" (p. 225).

1. Results from this study were reported in several media outlets, including nippon.com, which presents dossiers in several languages: www.nippon.com/fr/indepth/a007/ (accessed on 25 March 2014). Two other components of the project are a study of the role of cinema and popular culture in forming memories of the war (University of Hawai'i Press, to be published) and a study of the opinion of elite intellectuals in politics and the media in Japan, China (PRC), South Korea, and the United States on historical disputes (Stanford University Press, to be published). Finally, a comparison of memories of the Second World War in Europe and Asia has just been published in collaboration with Daniel Chirot: Confronting Memories of World War II: European and Asian Legacies (University of Washington Press, 2014).

\section{NOTES}

2. In 2007, Japan's Education Ministry demanded that part of the description of mass suicide by 1,000 Okinawans in the summer of 1945 be omitted, especially concerning the Imperial Army's possible role in the event. The ministry's demand provoked hostility among Okinawans, who seek to preserve the memory of their sacrifice for other Japanese.

3. Interestingly and revealingly, Li Weike is alone in "forgetting" Taiwan's textbooks in a comparative study. 


\section{AUTHORS}

YVES RUSSELL

Yves Russell is a PhD candidate at EHESS (School for Advanced Studies in Social Sciences), Paris (yvesrussell@gmail.com). 